\title{
Biosynthesis of Rhamnolipid Biosurfactant by Newly Isolated Marine Bacterium Methylobacterium mesophilicum MTCC 6839 from Oil Contaminated Sites at Alang Coast, Gujarat, India
}

\author{
T. K. Vyas" ${ }^{* *}$ and B. P. Dave \\ Dept. of Life Sciences, Bhavnagar University, Bhavnagar Gujarat (364 001), India \\ "Presently Food Quality Testing Laboratory, N. M. College of Agriculture, Navsari Agricultural University, \\ Navsari, Gujarat (396 450), India
}

\section{Article History}

Manuscript No. AR1496

Received in $26^{\text {th }}$ November, 2015

Received in revised form $25^{\text {th }}$ January, 2016

Accepted in final form $6^{\text {th }}$ February, 2016

\section{Correspondence to}

"E-mail: vyastrupti@hotmail.com

\section{Keywords}

Biodegradation, crude-oil, hydrophobicity, Methylobacterium, rhamnolipid, emulsification

\begin{abstract}
Oil spillage into marine environment either from seeps or from anthropogenic sources, is subject to pose a major environmental pollution. Alang coast $\left(21^{\circ} 21^{\prime} \mathrm{N}, 72^{\circ} 12^{\prime} \mathrm{E}\right), 60$ $\mathrm{km}$ from Bhavnagar, Gujarat, India, is known for its extensive shipbreaking activities. These activities release tonnes of oil into the marine environment, polluting the marine ecosystem and thus, threatening biological diversity. Methylobacterim mesophilicum MTCC 6839, a potential marine crude oil degrader was isolated from Alang Coast. In the present study, M. mesophilicum has been evaluated for physiological changes during oil biodegradation. Cells produced biosurfactant, an amphiphilc molecule and thus increased emulsification activity of oil. It produced rhamnolipid biosurfactant as analyzed by thin layer chromatography (TLC) and Fourier transform infrared spectroscopy (FTIR). It has been also examined for surface hydrophobicity and emulsification activity as a function of biosurfactant production. Results indicate that cells altered their cells surface hydrophobicity when grown on a hydrophobic carbon source. Also, an increasing in biosurfactant production led to increase in cell surfacehydrophobcity and emulsification activity. The results thus, indicate the potential role of cell surface hydrophobicity and emulsification activity in response to biosurfactant production by marine $M$. mesophilicum in remediation of crude oil contaminated sites. Biosurfactant production is significantly correlated with degradation and emulsification activity at 0.001 level whereas, with growth at 0.01 level. Thus, isolated MTCC 6839 can be used for bioremediation of oil contaminated marine sites.
\end{abstract}

\section{Introduction}

Petroleum production and transportation are inevitably bound up with environmental issues in aquatic and terrestrial environments. Recently there is increasing awareness for bioremediation strategies as clean technology to remediate such polluted environments, as it is eco-friendly and cost effective. Due to oil spills soil or water surfaces covers with it, making the oxygen unavailable for the biota that results in environmental disasters such as the death of oxygen-dependent organisms (Assadi and Tabatabaee, 2010). The use of surfactants is among the almost effective ways of removing hydrocarbons from the environment. Originally, biosurfactants attracted attention as hydrocarbon dissolving agents in the late 1960s, and their applications have been greatly extended in the past five decades as an improved alternative to chemical surfactants (Nasrollahzadeh et al., 2007)

Biosurfactants (BS) are amphiphilic molecules mainly produced by microorganisms including bacteria, yeast and fungi (Satpute et al, 2010). Biosurfactants (BS) are amphiphilic molecules have both hydrophilic and hydrophobic moieties and are able to display a variety of surface activities that help to solubilize hydrophobic substrates (Desai and Banat, 1997; Kokare et al., 2007). Due to their amphiphilic nature, biosurfactants increase the surface area of hydrophobic compounds and thus increase the bioavailability of such compounds. Hence, biosurfactant producing microorganisms play an important role in the accelerated bioremediation of hydrocarbon contaminated sites (Del'Arco and Franca, 2001; 
Rahman et al, 2002). Interest in research into and application of BS is gaining increased momentum attributable to their environmental friendly and lower toxicity in comparison to synthetic surfactant (Shete et al., 2006; Perfumo et al., 2010).

Few reports on biodegradation of various compound like methyl tert-butyl ether (MTBE) (Mo et al., 1997; Hanson et al., 1999; Ohkubo et al., 2009), EDTA (Thomas et al., 1998) and oil degradation (Dourado et al., 2012) by Methylobacterium sp. have been reported. However, Methylobacterium mesophilicum has not yet been reported as rhamnolipid biosurfactant producer. In the present study, characterization and production of biosurfactant during crude oil degradation has been examined. Its correlation with emulsification activity and cell-surface hydrophobicity during degradation has also been evaluated.

\section{Materials and Methods}

\subsection{Organisms}

M. mesophilicum MTCC 6839 isolated by author from crude oil contaminated sea water and sediments collected from Alang coast, Gujarat, India. Isolate previously isolated in year of 2003(Vyas and Dave, 2004) and identified in our laboratory (Vyas and Dave, 2007). Present work was carried out during 2013-2014.

\subsection{Plate assays for BS production}

Blood agar and blue agar plate assay were used for detection of BS production by isolate as described by Vyas and Dave (2011). Plates were incubated for 24-48 hrs at room temperature. Hemolysis and blue haloes on blood agar and blue agar plate respectively indicate BS production.

\subsection{Chemical characterization and quantification of $B S$}

For chemical characterization and quantification of BS, partially purified BS was used. BS was partially purified, characterized by TLC (Silica gel 60G F254, Merck) and FTIR spectroscopy (Nicolet IR200 FT-IR Spectrometer) and quantified as mentioned previously by Vyas and Dave (2011).

\subsection{Cell-surface hydrophobicity by MATH assay}

Cell-surface hydrophobicity was measured as per the method described by Rosenberg et al, (1980) and calculated as

$$
\begin{aligned}
& \% \text { Hydrophobicity }=\frac{(1-\mathrm{A} 400 \text { of aqueous phase }}{\mathrm{A} 400 \text { of cell suspension })} \times 100 \\
& \text { 2.5. Emulsification activity }
\end{aligned}
$$

\subsection{Emulsification activity}

Emulsification activity was measured as emulsification index-E24 as described by Cooper and Goldenberg (1987). After $24 \mathrm{~h}$, emulsification activity was measured as:

E24 $(\%)=($ Height of emulsion/ total height $) \times 100$

\subsection{Growth and degradation}

Temporal effects of biosurfactant production, cell-surface hydrophobicity and emulsification activity on growth and degradation rates were examined to observe the correlation with growth and degradation, from $4^{\text {th }}$ day onwards at 6 days intervals upto, 40 days. Cells were grown in Bushnell and Hass medium (BHM) supplemented with $5 \mathrm{~g} \mathrm{~L}^{-1}$ of crude oil and $\mathrm{N}$ $(1 \%), \mathrm{P}(0.5 \%)$ and $\mathrm{K}(0.01 \%)$ (previously optimized) (Vyas and Dave, 2010). Growth was measured in terms of whole cell protein and degradation rates were measured as residual crude oil (Vyas and Dave, 2007).

\subsection{Statistical Analyses}

Data were analyzed for Pearson correlation coefficient for all the three parameter i.e., biosurfactant production, cell-surface hydrophobicity and emulsification activity with growth and degradation using SPSS 14.0.

\section{Results and Discussion}

\subsection{Plate assay}

Crude oil degrading marine Methylobacterium mesophilicum MTCC 6839 was examined for the production of biosurfactant by blue agar and blood agar plate assays. Cells hemolyse RBC indicates biosurfactant production and blue haloes around colony on blue agar suggests there rhamnolipd biosurfactant nature.

\subsection{Characterization of $B S$}

The biosurfactant produced by the isolate was found to be lipid as it produced fluorescent pink colored spots on TLC on spraying with rhodamine B reagent. Determination of the type of lipid i.e., phospholipids, glycolipids and neutral lipids revealed the surfactant to be glycolipid as it produced brown spots. M. mesophilicum showed $\mathrm{R}_{\mathrm{f}}$ value 0.69 almost identical to the authentic glycolipids (Cho et al., 1998). Phospholipids and neutral lipids could not be detected.

BS of glycolipid type is generally known to have hexose as a sugar component. One exception is rhamnolipid, which has deoxyhexose as the hydrophilic structure in glycolipid. UVVis spectral analysis had been used to identify the hexose or deoxyhexose component of glycolipid. Spectra of surfactant with no shoulder at $440 \mathrm{~nm}$, confirmed the presence of deoxyhexose (rhamnose).

Detection of type of sugar by TLC analysis, revealed the presence of rhamnose as it developed green colored spots on spraying with anisaldehyde $\mathrm{H}_{2} \mathrm{SO}_{4}$ reagent with $\mathrm{Rf}$ value 0.63 identical to standard rhamnose sugar $(\mathrm{Rf}=0.63)$. The identification of rhamnose was further confirmed by cochromatography. Thus, by both TLC and UV-Vis spectral analyses, the biosurfactant produced by the isolates was 


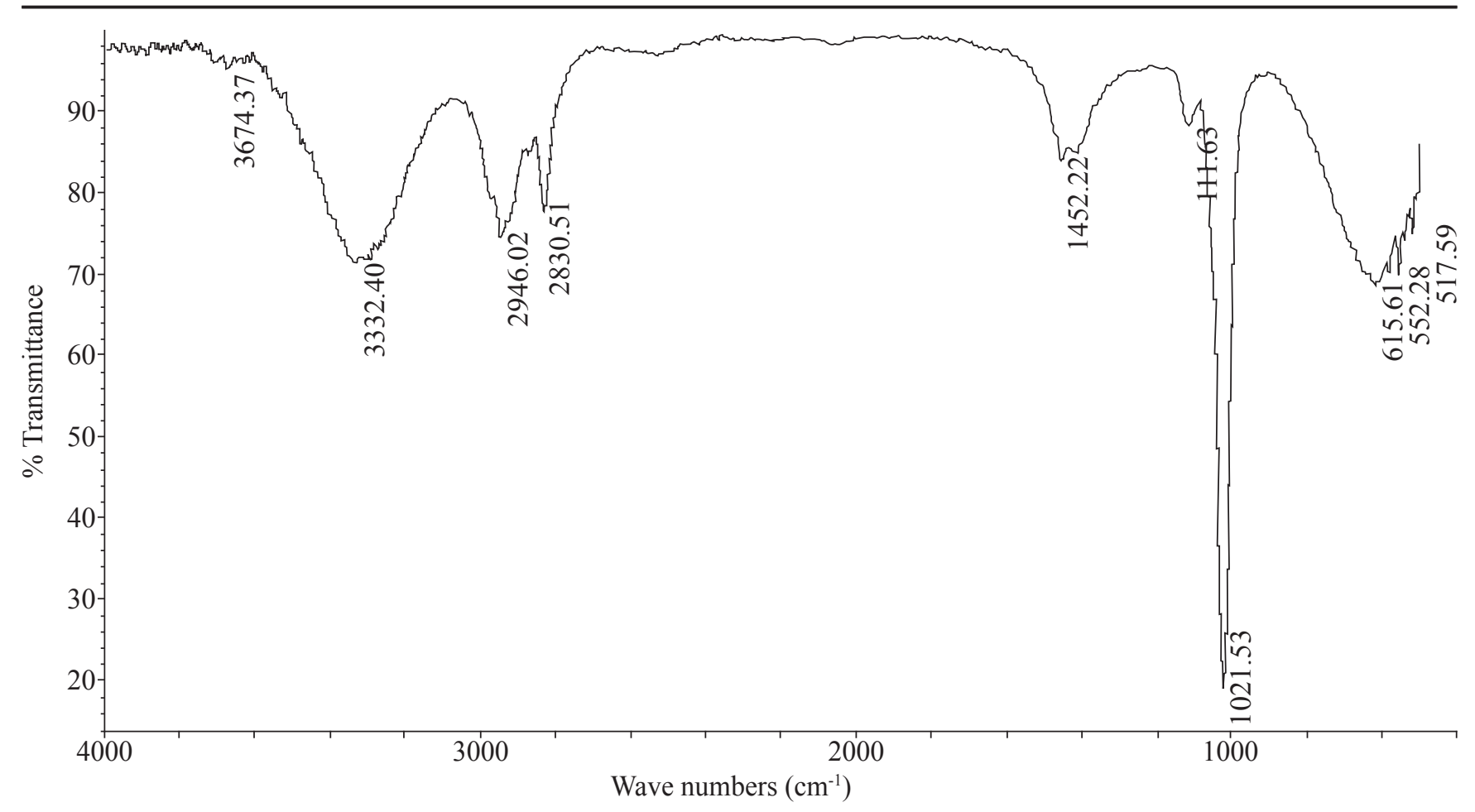

Figure 1: FTIR spectra of biosurfactant from M. mesophilicum MTCC 6839

characterized as rhamnolipid. These findings support the fact that rhamnolipids have hemolytic properties.

Typical FTIR spectra of BS for the band region $4000-400 \mathrm{~cm}^{-1}$ (Figure 1). The absorption bands include $3674 \mathrm{~cm}^{-1}$ shows O-H stretch characteristics of free hydroxyl or alcohol group. $3332 \mathrm{~cm}^{-1}$ broad peak indicates the O-H stretching. Peaks at $2946 \mathrm{~cm}^{-1}$ and $2830 \mathrm{~cm}^{-1}$ indicate the C-H stretching for alkyl and $\mathrm{C}-\mathrm{H}$ stretching for aldehyde respectively. $1452 \mathrm{~cm}^{-1}$ peak indicates the $\mathrm{C}-\mathrm{H}$ stretching of alkanes. The ester carbonyl was also proved from the band at $1111 \mathrm{~cm}^{-1} .1021 \mathrm{~cm}^{-1}$ indicates $\mathrm{C}-\mathrm{O}$ stretching. Various peaks at $615 \mathrm{~cm}^{-1}, 562 \mathrm{~cm}^{-1}$ and 517 $\mathrm{cm}^{-1}$ indicate the aliphatic alkyl stretching. Thus, TLC, UV-Vis spectral and FTIR analyses, of the biosurfactant produced by the isolate was characterized as rhamnolipid and quantified as rhamnose equivalent $\left(\mathrm{RE} \mathrm{mg} \mathrm{ml}^{-1}\right)$.

\subsection{Quantification of $B S$}

The involvement of surfactant in hydrocarbon assimilation/ uptake was monitored by correlating biosurfactant production as a function of emulsification activity. Biosurfactant production increases as growth rate increase. However, biosurfactant production was maximum $\left(0.59 \mathrm{mg} \mathrm{ml}^{-1}\right)$ on $34^{\text {th }}$ day of incubation, after maximum growth $\left(0.91 \mathrm{mg} \mathrm{ml}^{-1}\right)$ on $28^{\text {th }}$ day of incubation. Thereafter production and growth decreased (Figure 2). Correlation of biosurfactant with degradation $(p=0.000)$ and emulsification activity $(p=0.001)$ is significant at 0.001 level. Growth $(p=0.007)$ is significant at 0.01 level while non significant with hydrophobicity $(p=0.081)$.

\subsection{Cells surface hydrophobicity}

Cells-surface hydrophobicity increased with increase in biosurfactant production. Maximum hydrophobicity ( $80 \%)$ was attained on $22^{\text {nd }}$ day of incubation. Cells make their surface more hydrophobic to increase the availability of hydrophobic compounds. Hence thereafter cells show higher biodegradation on $28^{\text {th }}$ day of incubation (Figure 2). However, cell-surface

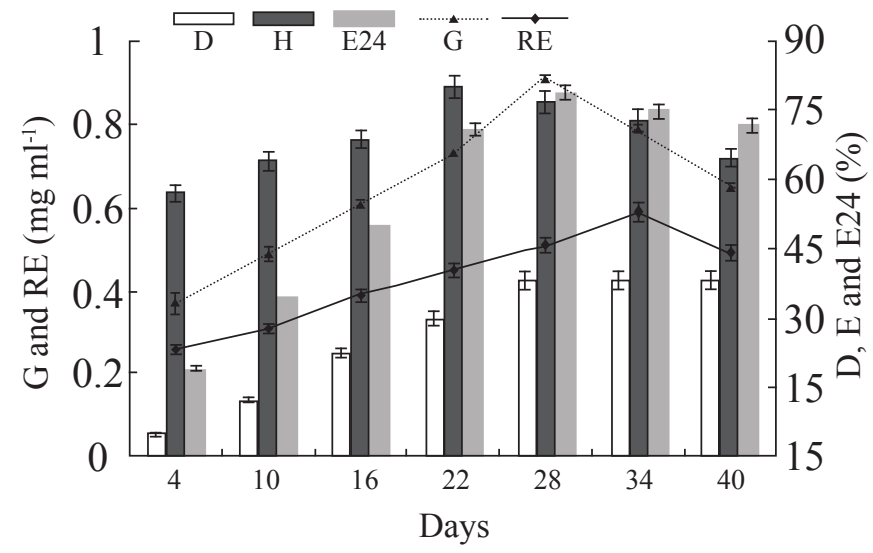

Figure 2: Temporal effect of biosurfactant production, cellsurface hydrophobicity, mulsification activity on growth and degradation by M. mesophilicum (error bar indicats SD) (D: Degradation; E: emulsification activity; G: growth; H: Hydrophobicity; RE: rehmnose equivalent; error bar indicates standard deviation) 
hydrophobicity was decreased with further incubation and on the $40^{\text {th }}$ day of incubation cells lost hydrophobicity (65\%). Hydrophobicity correlates with growth $(p=0.010)$ significantly at 0.01 level. While, emulsification activity $(p=0.025)$ at significant 0.05 level and non significant with biodegradation $(p \geq 0.05, p=0.076)$.

\subsection{Eumlsification activity}

Emulsification activity showed that increase its activity with increase in biosurfactant production (Figure 2). Maximum emulsification activity (79\%) was observed on the day of maximum degradation $(40 \%)$ i.e., on $28^{\text {th }}$ day of incubation. Correlation of emulsification activity with degradation $(p=0.000)$ is significant at 0.001 level and with growth $(p=0.002)$ at 0.01 level. Alang, situated $60 \mathrm{~km}$ from Bhavnagar coast, is the largest ship-breaking yard in Asia. These activities release tonnes of oil into the marine environment, polluting the marine ecosystem and thus, threatening biological diversity. Bioremediation in general aims at providing cost effective, contaminant specific treatment to reduce the concentration of individual or mixed environmental contaminants (Head, 1998).

$\mathrm{Li}$ and $\mathrm{Gu}$ (2007) have reported that complete degradation of dimethyl isophthalate requires the biochemical cooperation between Klebsiella oxytoca Sc and Methylobacterium mesophilicum Sr. Salam and co worker (2015) have isolated Methylobacterium Mesophilicum from tropical hydrocarboncontaminated soil which is able to degrade used engine oil. Dourado et al. (2012) isolated Methylobacterium strains from mangrove samples collected in Bertioga, SP, Brazil. They have reported that Methylobacterium were found to be tolerant to three metals cadmium, lead, and arsenic and have the potential to bioremediate mangrove environments contaminated by oil spills by immobilizing the heavy metals present in the oil. Sakalle and Rajkumar (2009) have isolated Methylobacterim sp. form Alang, however, biosurfactants have not been detected. Their results are contradictory to our finding that $M$. mesophilicum MTCC 6839 produce rhamnolipid biosurfactant.

Generally Psedomonas spp. has been known to produce rhamnolipid type biosurfactant. Christova el al. (2004) reported rhamnolipid biosurfactant production by Renibacterium salmoninarum 27BN during growth on $\mathrm{n}$-Hexadecane. Moreover, earlier we have reported rhamnolipid production by Nocardia otitidiscaviarum MTCC 6471 instead of trehalolipid biosurfactant (Vyas and Dave, 2011).

M. mesophilicum MTCC 6839 produced rhamnolipid biosurfactant and was able to degrade $40 \%$ of the oil when medium was supplemented with $5 \%$ of oil after 34 days of incubation. Cells first increase their hydrophobicity and insert more amphiphilic molecules in their cell wall making themselves equipped to attach on hydrophobic compounds. Due to this ability cells attach to the hydrophobic compounds and solubilize it by biosurfactant production. Hence, maximum emulsification activity was observed after the cells attained maximum hydrophobicity. Thereafter cells lost the hydrophobicity. Bredholt et al. (2002) have reported that cells develop a strong hydrophobic character during exponential phase $(100 \%)$, which was lost when cells entered stationary phase which supports our finding.

Emulsification reduces the size of oil droplets to less than $1 \mu \mathrm{m}$, increasing the interfacial area. Our results strongly suggest that greater the interfacial area, greater the growth rate and cell-surface hydrophobicity and hence, higher emulsification activity. Based on the results obtained, it can be proposed that biosurfactant produced by the isolates pseudosolubilize crude oil in the medium. The cells up take this pseudo-solubilised crude oil via interaction with hydrophobic cell surface. Pasternak and Kołwzan (2013) have reported that Methylobacterium sp. GPE1 strain isolated from a former gasworks, decrease of surface tension up to $61 \mathrm{mN} \mathrm{m}^{-1}$ during their growth on carbazole.

Thus, as the organisms increase their hydrophobicity, they attach to the surface of oil and solubilize it through biosurfactant production, their by increasing the rate of degradation by increasing emulsification activity. The present study indicates acceleration of oil degradation rates through increasing in biosurfactant production, cell surface hydrophobicity and emulsification activity.

There are a number of reports on production on rhamnolipid production by Pseudomonas spp. As per the present study, $M$ mesophilicum is also a producer of rhamnolipid biosurfactants. As soon as hydrophobic compounds are released into the nature, cells make their cell-surface more hydrophobic, attach to the poorly soluble compounds and by secreting biosurfactant, solubilize the hydrophobic compounds. Thus, M. mesophilicum which is still not reported as rhamnolipid producer can be effectively used for bioremediation of crude oil contaminated marine sites.

\section{Conclusion}

There are a number of reports on production on rhamnolipid production by Pseudomonas spp. As per the present study, M. mesophilicum is also produce rhamnolipid biosurfactants $\left(0.59 \mathrm{mg} \mathrm{ml}^{-1}\right)$. As soon as hydrophobic compounds are released into the nature, cells make their cell-surface more hydrophobic, attach to the poorly soluble compounds and by secreting biosurfactant, solubilize the hydrophobic compounds. Thus, M. mesophilicum which is still not reported as rhamnolipid 
producer can be effectively used for bioremediation of crude oil contaminated marine sites.

\section{Acknowledgement}

The authors thank Ministry of Earth Sciences (MoES), Government of India, New Delhi, for the financial assistance (DOD/12-MMDP/4/01/(P-2)).

\section{References}

Assadi, M.M., Tabatabaee, M.S., 2010. Biosurfactants and their Use in Upgrading Petroleum Vacuum Distillation Residue: A Review. International Journal of Environmental Research 4, 549-572.

Bredholt, H., Bruheim, P., Potocky, M., Eimhjellen, K., 2002: Hydrophobicity development, alkane oxidation and crude oil emulsification in Rhodococcus species. Canadian Journal of Microbiololgy 48, 295-304.

Cho, J-H., Jeong, Y-L., Park, O-J., Yoon, B-D., Yang, J.W., 1998. Characterization of glycolipid biosurfactants from an isolated strain of Pseudomonas aeruginosa YPJ 80. Journal of Microbiology \& Biotechnology 86, 645-649.

Christova, N., Tuleva, B., Lalchev, Z., Jordanova, A., Jordanov, B., 2004. Rhamnolipid biosurfactants produced by Renibacterium salmoninarum $27 \mathrm{BN}$ during growth on n-hexadecane. Z. Naturforsch C 59, 70-74.

Cooper, D.G., Goldenberg, B.G., 1987. Surface-active agents from two Bacillus species. Applied and Environmental Microbiology 53, 224-229.

Del'Arco, J.P., de Franca, F.P., 2001. Influence of oil contamination levels on hydrocarbon biodegradation in sandy sediments. Environmental Pollution 110, 515-519.

Desai, J.D., Banat, I.M., 1997. Microbial production of surfactants and their commercial potential. Microbiol. Molecular Biology Review 61, 47-64.

Dourado, M.N., Ferreira, A., Araujo, W.L., Azevedo, J.L., Lacava, P.T., 2012. The diversity of endophytic methylotrophic bacteria in an oil-contaminated and an oil-free mangrove ecosystem and their tolerance to heavy metals. Biotechnology Research International 1-8 (doi:10.1155/2012/759865).

Hanson, J.R., Ackerman, C.E., Scow, K.M., 1999. Biodegradation of methyl tert-butyl ether by a bacterial pure culture. Applied and Environmental Microbiology $65,4788-4792$.

Kokare, C.R., Kadam, S.S., Mahadik, K.R., Chopade, B.A., 2007. Studies on bioemulsifier production from marine Streptomyces sp. S1. Indian Jouranal of Biotechnology 6(1), 78-84.
Li, J., Gu, J.D., 2007. Complete degradation of dimethyl isophthalate requires the biochemical cooperation between Klebsiella oxytoca Sc and Methylobacterium mesophilicum $\mathrm{Sr}$ isolated from wetland sediment. Science of the Total Environment 380, 181-187.

Mo, K., Lora, C.O., Wanken, A.E., Javarnmardian, M., Yang, X., Kulpa, C.F., 1997. Biodegradation of methyl $t$-butyl ether by pure bacterial cultures. Applie Microbiology and Biotechnology 47, 69-72.

Ohkubo, N., Hashimoto, A.H., Iwasaki, K., Yagi, S. 2009. Biodegradation of Methyl tert-Butyl Ether by Mycobacterium spp. Journal of Environmental Biotechnology 9, 113-122.

Pasternak, G., Kołwzan, B., Bernard-Baures, G., Rybak, J., Morzik, A., 2012. Physiological characterization of carbazole degrading bacteria isolated from a former gasworks site. Environmental Protection Engineering 38(2), 121-126.

Pasternak, G., Kołwzan, B., 2013. Surface tension and toxicity changes during biodegradation of carbazole by newly isolated methylotrophic strain Methylobacterium sp. GPE1. International Biodeterioration \& Biodegradation 84, 143-149.

Perfumo, A., Smyth, T.J.P., Marchant, R., Banat, I.M., 2010. Production and roles of biosurfactants and bioemulsifiers in accessing hydrophobic substrates. In: Kenneth, N. Timmis. (Eds), Handbook of Hydrocarbon and Lipid Microbiology. Springer-Verlag Berlin Heidelberg, 1502-1512.

Rahman, K.S.M., Banat, I.M., Thahira-Rahman, J., Thayumanavan, T., Lakshmanaperumalsamy, P., 2002. Bioremediation of gasoline contaminated soil by a bacterial consortium amended with poultry litter, coir pith and rhamnolipid biosurfactant. Bioresource Technology 81, 25-32.

Rosenberg, M., Gutnick, D.L., Rosenberg, E., 1980. Adherence of bacteria to hydrocarbons: a simple method for measuring cell-surface hydrophobicity. FEMS Microbiology Letter 9, 29-33.

Sakalle, K., Rajkumar, S., 2009. Isolation of crude oil degrading marine bacteria and assessment for biosurfactant production. The Internet Journal of Microbiology 7, 2009

Salam, L.B., Obayori, O. S., Raji, S. A., 2015. Biodegradation of used engine oil by a methylotrophic bacterium, Methylobacterium mesophilicum isolated from tropical hydrocarbon-contaminated soil . Petroleum Science and Technology 33(2), 1-8.

Satpute, S.K., Banpurkar, A.G., Dhakephalkar, P.K., Banat, I.M., Chopade, B.A., 2010. Methods for investigating 
biosurfactants and bioemulsifiers: a review. Critical Review in Biotechnology 30(2), 127-144.

Shete, A.M., Wadhawa, G., Banat, I.M., Chopade, B.A., 2006. Mapping of patents on bioemulsifier and biosurfactant: A review. Journal of Scientific and Industrial Research $65,91-115$.

Thomas, R.A.P., Lawlor, K., Bailey, M., Macaskie, L.E., 1998. Biodegradation of metal-EDTA complexes by an enriched microbial population. Applied \& Environmental Microbiology 64, 1319-1322.

Vyas, T.K., Dave, B.P., 2011. Production of biosurfactant by Nocardia otitidiscaviarum and its role in biodegradation of crude oil. International Journal of Environmental Science \& Technology 8, 425-432.
Vyas, T.K., Dave, B.P., 2004. Biodegradation of crude oil by marine bacteria at Alang (Bhavnagar) sea coast. In: Proceedings of National Academy of Science India, 74, B(II), 153-160.

Vyas, T.K., Dave, B.P., 2007. Effect of crude oil concentrations, temperature and $\mathrm{pH}$ on growth and degradation of crude oil by marine bacteria. Indian Journal of Marine Science 36, 76-85.

Vyas, T.K., Dave, B.P., 2010. Effect of addition of nitrogen, phosphorus and potassium fertilizers on biodegradation of crude oil by marine. Indian Journal of Marine Science 39, 143-150. 